This is a so-called personal version (author's manuscript as accepted for publishing after the review process but prior to final layout and copyediting) of the article:

Vaara, Eero. 2011. On the Importance of Broader Critique:Discursive Knowledge Production in Management Education . British Journal of Management, 22: 564-566.

Researchers are kindly asked to use the official publication in references.

\title{
On the Importance of Broader Critique: Discursive Knowledge Production in Management Education
}

\author{
Eero Vaara \\ Department of Management and Organisation, Hanken School of Economics, \\ PO Box 479, Arkadiankatu 22, \\ 00101 Helsinki, Finland \\ and EMLYON Business School, 23 av. Guy de Collongue, BP 174, \\ 69132 Ecully Cedex, France \\ Email: eero.vaara@hanken.fi
}


The 25th anniversary of the British Academy of Management gives rise to celebration and reflection. I would like to add to this discussion by emphasizing the importance of broader critical reflection of the systems that we are part of. This is an objective that sociologists and philosophers have advocated time and again. For example, Foucault promoted critical analysis of bodies of knowledge and the way in which they govern our lives (Foucault, 1994). Bourdieu in turn underscored the importance of reflexivity in general and advocated the sociology of sociology (Bourdieu, 1990). Similar ideas have also been promoted by critically oriented management scholars (Alvesson and Willmott, 2003).

I have an important example in mind: discursive knowledge production in management education. Although management education has received a great deal of critical attention in recent years (Antonacopoulou, 2010; French and Grey, 1996; Khurana, 2007; Mintzberg, 2004), this is an area that warrants continuous attention. This is not least because of its huge expansion and central role in the globalization of all kinds of management practices and values (Khurana, 2007).

I wish to advocate analyses that take a broadview on management education systems and their discursive and ideological underpinnings. Following Foucault, I focus on the central role of discourses in management knowledge. In this view, discourses are an essential part of managerial practice - to the extent that we take these discourses for granted. Management discourses, however, are not neutral but carry with them values and ideological assumptions. In particular, management discourses seem to be linked with neo-liberalism and instrumentalism - which can be seen as root causes for the ethical problems pointed out in managerial practice (Khurana, 2007; Mintzberg, 2004). Why is this the case? Foucault would say that these discourses have evolved over time with practice and that power and knowledge are always intertwined. Bourdieu would emphasize that education systems tend toreproduce the interests and values of the elite in society. Interestingly, for example Khurana's (2007) historical overview of MBA education supports these arguments by pointing to the close linkage of business interests and the development of business schools.

Drawing on Bourdieu (1991, 1996), I seemanagement education as a complex system with its own sub-fields and rules of the game. In this view, management education produces not only intellectual capital (or 'knowledge' as we conventionally see it) but also social capital (social contacts and networks) and especially symbolic capital (dispositions that distinguish people who have gone through such education from others)(Vaara and Fay", 2011). Discourses play 
a central role as intellectual capital; students and managers are able to use discourses instrumentally to understand problems and challenges and to develop solutions. Discourses are also an essential means to create social capital in connecting people. However, it is the linkage of discourses and symbolic capital that I find most intriguing - and least understood in critical analyses of management education.

This form of symbolic capital means abilities to use management discourses to speak in a convincing way about management issues; this creates a special authority position for the student or manager in question. To put it bluntly, by using the most fashionable buzzwords or framing things in ways that create 'spin', students and managers show expertise and competence that others lack. In this way, they become 'knowledgeable' actors who can distinguish themselves from others. This kind of discursive positioning is central both in management education and in managerial practice that to a large extent deal with communication. I am not saying that all this discursive work is problematic; on the contrary, mastery of the newest theories may be very useful and authority construction crucial to be able to succeed as a manager. However, I am arguing that this discursive work involves a great risk if it means voluntary adoption and use of discourses that reproduce problematic values and ideological assumptions. In other words, we are facing a two-fold problem: management discourses often carry problematic values and assumptions, and at the same time actors are very willing to spread these discourses (without critical reflection).

This raises important questions about the ways in which management education creates, transforms, spreads, legitimates and naturalizes management discourses (Abrahamson, 1996). This system is complex as it involves researchers and teachers in universities, business schools and other education institutions, gurus, consultants and other experts, the business press and other media - and ultimately practising managers who reproduce or at times transform prevailing discourses. Thus, it is difficult to pinpoint any particular actor, and I certainly do not wish to exaggerate the role of any one academic in this knowledge production. However, I do want to point out that there is a linguistic division of labour according to which we as academics play a crucial role as gatekeepers of the profession(Schildt, Mantere and Vaara, 2011). That is, we as scholars in academic institutions do have a great deal of influence on the legitimation and naturalization of particular management discourses.

So what does critical reflection imply in this context? First, many aspects of this complex system of management education are still poorly understood. For example, we need to 
critically examine whether management discourses are characterized by 'scienticity' only to artificially legitimate management knowledge as science (see also Sandberg and Tsoukas, 2011). Similarly, we should study to what extent dominant management discourses - as argued - reflect and reproduce western worldviews, ethnocentrism, managerialism, instrumentalism and gendered (masculine) practices. It is also important to examine whether -and if so why - these discourses impede broader ethical considerations.

Second, it is crucial to take pedagogy seriously, to resist the reproduction of problematic discourses and practices and to promote positive alternatives in our teaching (see also Antonacopoulou, 2010). We should also make sure that we as management scholars are not rewarding 'empty rhetoric’ among students. To go back to Bourdieu, he frequently warned scholars about judging students on the basis of their rhetorical ability or lack of ability. Third, we as scholars can also engage in critical reflection in society at large. A part of this can be critique of dominant discourses and their values and ideological assumptions. Such engagement is not easy, but social sciences provide many examples of such activism, including Foucault and Bourdieu. 


\section{References}

Abrahamson, E. (1996). 'Management fashion’, Academy of Management Review, 21, pp. 254-285.

Alvesson, M. and H. Willmott (2003). Studying Management Critically. London: Sage.

Antonacopoulou, E. P. (2010). 'Making the business school more “critical'? reflexive critique based on phronesis as a foundation for impact', British Journal of Management, 21 (special issue), pp. 6-25.

Bourdieu, P. (1990). In Other Words. Essays Towards a Reflexive Sociology. Stanford, CA: Stanford University Press.

Bourdieu, P. (1991). Language and Symbolic Power. Cambridge, MA: Harvard Business School Press.

Bourdieu, P. (1996). Distinction: A Social Critique of the Judgement of Taste. London: Routledge.

Foucault, M. (1994). Power: Essential Works of Foucault, 1954-1984, vol. III, edited by J. D. Faubion. New York: The New Press.

French, R. and C. Grey (1996). Rethinking Management Education. London: Sage.

Khurana, R. (2007). From Higher Aims to Hired Hands: The Social Transformation of American Business Schools and the Unfulfilled Promise of Management as Profession. Princeton, NJ: Princeton University Press.

Mintzberg, H. (2004). Managers not MBAs: A Hard Look at the Soft Practice of Managing and Management Development. San Francisco, CA: Berrett-Koehler.

Sandberg, J. and H. Tsoukas (2011). 'Grasping the logic of practice: theorizing through practical rationality’, Academy of Management Review, 36, pp. 338-360.

Schildt, H., S. Mantere and E. Vaara (2011). 'The linguistic division of labor in institutional work', Journal of Management Inquiry, 20, pp. 82-86.

Vaara, E. and E. Fay” (2011). 'How can a Bourdieusian perspective aid the analysis of MBA education?’, Academy of Management Learning and Education, 10, pp. 27-39. 